\section{St. Paul's School Field Club}

The fiftieth anniversary of the moving of St. Paul's School from the City of London to West Kensington, on the western border of Greater London, coincides with the opening of the new biological laboratories. The occasion was celebrated at Apposition on July 5, when the Field Club held an exhibition of its work. After the speeches, the display was visited by the High Master, the Governors of the School and many hundreds of boys and parents. The numerous exhibits indicated how wide are the interests of the members, in all branches of biology and natural history. Worthy of special mention were a large number of experiments in plant physiology, an investigation of irregular nutrition in plants (mycorrhiza, saprophytes and parasites), an ecological survey of sea-shore life and a study of heath and moorland associations, with special reference to mosses. Collections were shown of insects, ferns, seaweeds and fresh-water organisms, while a spirometer proved very popular. The Club, which is nearing its fortieth anniversary, has always been a great boon to the naturalists of the School, and in recent years has worked in close co-operation with the Biological Department. A great deal of field work is done, and in the winter, lectures are given by members and others on subjects of which they have made a special study. The Club is exceptionally fortunate in being at the same time within easy reach of the countryside and the authorities at the Natural History Museum, Kew Gardens and the Zoo.

\section{Harvey and Literature}

THE June issue of the Proceedings of the Royal Society of Medicine contains a paper read by Dr. D. F. Fraser-Harris before the Section of the History of Medicine on William Harvey's knowledge of classical, medieval, renaissance and contemporary literature. Harvey's acquaintance with classical literature is shown by the fact that his works contain references to twenty-five Greek writers ranging from Thales in the seventh century B.c. to Suidas, who flourished about A.D. 975, and including among others Hippocrates, Plato, Euclid of Megara, Erasistratus, Aristotle and Menander, as well as allusions to fourteen Latin writers from Virgil to Pipinus and Migaldus, including Varro, Terence, Seneca, the elder Pliny, Celsus and Ulpian. Three medieval writers are mentioned by Harvey, namely, Avicenna, Averroes and Albertus Magnus. Of the thirty-two renaissance and contemporary authors whom he quotes, the best known are Jacobus Sylvius, Fracastor, J. C. Scaliger, Fernel, Vesalius, Eustachius, Descartes, De Thou, Sennert, Pecquet, Baillou and Riolan. The only English writer mentioned is Francis Bacon, whose phrase "to enter upon our second vintage" is quoted in De Generatione. In the manuscript notes to his lectures, Harvey also cites seven authors whom he mentions nowhere else, namely, Plautus, Horace, Cæsar, Cicero, Vitruvius, Nicolas Massa and Archangelo Piccolhomini. Most, but by no means all, of the references are to subjects of biological importance, the exceptions being passages in the Eclogues,
Georgics and Aeneid of Virgil and Terence's Adelphi. The conspicuous absence of any mention of Cæsalpinus, whom many Italian physiologists even to-day. regard as the discoverer of the circulation of the blood, and of Servetus, in Harvey's writings is attributed by Dr. Fraser-Harris to the fact that all but three copies of Servetus's book had been burned with him at the stake and that Harvey had found nothing of real value in Cæsalpinus's work.

\section{History of Organic Analysis}

PrIor to the introduction of elementary organic combustion analysis early in the nineteenth century, organic matter was analysed, over a period of nearly two centuries, by dry distillation, the results being expressed in weighed fractions of gaseous part, phlegma, oil and carbon residue, or later as carbonic oxide, carbonic acid, water, empyreumatic oil, acidic fraction, carburetted hydrogen and charcoal. The germ of this method is found in Beguin's "Élémens de Chymie", 1615. Nierenstein (Isis, 21, 123 ; 1934) has shown that there was a period of transition between the old and new methods of analysis, represented by a work of Nees von Esenbeck, Bischof and Rothe, "Die Entwickelung der Pflanzensubstanz", Erlangen, 1819, a rare book which is otherwise of considerable interest in the history of plant chemistry This contains tables, from which the chemical formulæ may be deduced from the results of distillation analyses, containing 981 'complexions' of the five binary compounds of oxygen, hydrogen and carbon, namely, water, carbonic oxide, carbonic acid, olefiant gas and marsh gas. These tables were the precursor of Richter's percentage tables now widely used.

\section{Wireless Communication and the Mercantile Marine}

The wireless communications of the mercantile marine are subject to regulations issued by the administrations of the maritime nations, which in turn are governed by the relevant parts of the General Radio Communication Regulations attached to the current Intermational Telecommunication Convention which came into force on January 15 , 1933. These regulations lay down the purposes for which the various bands of frequencies may be employed, certain bands being allocated exclusively to the mercantile marine, others to mobile services generally, while some are shared between mobile and other services. A certain amount of difficulty has been experienced in carrying out the communications of the mercantile marine owing to the interference which exists, especially in some areas near the coasts of Europe and the United States. In a paper read before the Wireless Section of the Institution of Electrical Engineers on May 2, Commander J. A. Slee made an analysis of the sources of this interference. Typical response curves of the average ship's receiver were given in the paper, and from these the field strengths of signals which can cause interference in the different sections of the marine communication band have been computed. The analysis dealt with both spark and valve trans. mitters, and also with the possible interference which 